\title{
Pyrethroid toxicity in silver catfish, Rhamdia quelen ${ }^{1}$
}

\author{
Francisco P. Montanha ${ }^{2 *}$, Luciana A.G. Galeb ${ }^{2}$, Jorge D. Mikos², Luciana N. Ganeco ${ }^{3}$, \\ Tiago P. Pereira ${ }^{4}$, Anne Tanaka ${ }^{4}$, Peter G. Kirschnik ${ }^{5}$ and Cláudia T. Pimpão ${ }^{5}$
}

\begin{abstract}
Montanha F.P., Galeb L.A.G., Mikos J.D., Ganeco L.N., Pereira T.P., Tanaka A., Kirschnik P.G. \& Pimpão C.T. 2012. Pyrethroid toxicity in silver catfish, Rhamdia quelen. Pesquisa Veterinária Brasileira 32(12):1297-1303. Laboratório de Pesquisa e Piscicultura, Pontifícia Universidade Católica do Paraná, Rodovia BR $376 \mathrm{Km} \mathrm{14}$, Bairro Costeira, São José dos Pinhais, PR 83010-500, Brazil. E-mail: chicopm28@yahoo.com.br

This study aimed to determine both the lethal and sublethal concentrations of Cypermethrin in young Silver Catfish (Brazilian "Jundiá", Rhamdia quelen) on aquatic environment during 96 hours, as well as to determine the Cypermethrin and Deltamethrin sublethal concentrations during the initial embryonic development period of Rhamdia quelen, and to verify their respective rates of fertilization, hatching and survival. Pyrethroid nowadays is a widely used insecticide, which presents a high toxicity to fish. In order to determine lethal and sublethal concentrations, 120 silver catfish were used; each one had an average weight of $59.58 \pm 4.50 \mathrm{~g}$ and an average size of $20.33 \pm 2.34 \mathrm{~cm}$. Concentrations used were 0 , $1.0,1.5,2.0,2.5,3.0,5.0,10.0,15.0$ and $20.0 \mathrm{mg}$ of Cypermethrin per liter of water (mg/L). Fish were exposed to the product in 30-liter fish tanks. In each fish tank there were four fishes and the product was applied three times, i.e., a total of twelve fish were exposed to the product at each application, and a total of 120 fish during the entire experiment $(\mathrm{n}=120)$. In order to determine the Cypermethrin and Deltamethrin sublethal concentrations during the initial embryonic development, ovulation induction was performed on female fishes using hormones, and then and egg collection was performed. The eggs were then hydrated and fertilized in Cypermethrin and Deltamethrin in different concentrations: $0.001,0.01,0.1,1.0$ and $10.0 \mathrm{mg} / \mathrm{L}$ of Cypermethrin and $0.001,0.01,0.1,0.5$ and $1.0 \mathrm{mg} / \mathrm{L}$ of Deltamethrin, in addition to the control group $(0 \mathrm{mg} / \mathrm{L})$. After fertilization, the eggs were kept in containers with the respective pesticides of Cypermethrin and Deltamethrin until hatching, when hatching rate was verified. Then the alevins, from the hatching, were kept on their respective concentrations of Cypermethrin and Deltamethrin so that the survival rate could be analyzed regarding the tested insecticides, during both 12-hour and 24-hour periods. Concerning the sublethal and lethal concentrations, Silver Catfish was sensitive to the tested concentrations of Cypermethrin, showing symptoms of poisoning, such as loss of balance, swimming alteration, dyspnea (they kept their mouths and opercula open), upright swimming and sudden spiral swimming movements. The intensity of such symptoms varied in proportion to the concentration used. The concentrations above $3.0 \mathrm{mg} / \mathrm{L}$ were considered lethal to the species, since every animal exposed to concentrations between 3.0 and $20.0 \mathrm{mg} / \mathrm{L}$ had died, while concentrations between 1.0 and $2.5 \mathrm{mg} / \mathrm{L}$ were considered sublethal. Lethal concentration of Cypermethrin to Silver catfish, in 96 hours, was 1.71 milligram per liter of water. Concerning the sublethal concentration of Cypermethrin and
\end{abstract}

\footnotetext{
${ }^{1}$ Received on March 14, 2012.

Accepted for publication on October 8, 2012.

${ }^{2}$ Mastering Animal Science, Pontifícia Universidade Católica do Paraná (PUCPR), Curitiba, PR, Brazil. Endereço particular: Rua Marechal Floriano Peixoto 1664, Siqueira Campos, PR 84940-000, Brazil. *Corresponding author: chicopm28@yahoo.com.br
}

\footnotetext{
${ }^{3}$ Centro de Produção e Propagação de Organismos Marinhos (CPPOM), PUCPR, Rodov. BR 376 Km 14, Bairro Costeira, São José dos Pinhais, PR 83010-500, Brazil.

${ }^{4}$ Graduate student in Veterinary Medicine, PUCPR, São José dos Pinhais, PR.

${ }^{5}$ Laboratório de Piscicultura e Pesquisa, PUCPR, Bairro Costeira, São José dos Pinhais, PR.
} 
Deltamethrin during the initial embryonic development, the results show that both pyrethroids had significantly decreased the analyzed parameters when comparing them with the control group. It was concluded that, even with the fish being more resistant to pyrethroids in comparison with other species, both the young animals and the ones in stage of embryonic development were susceptible to the effects of these pesticides.

INDEX TERMS: Pyrethroid toxicity, catfish, Rhamdia quelen, pesticides, embryonic development, fish.

RESUMO-- [Toxicidade dos piretróides sobre Jundiás, determinar a concentração letal e subletal da cipermetrina por via hídrica em 96 horas em jundiás (Rhamdia quelen) jovens, determinar a concentração subletal da cipermetrina e da deltametrina durante o período inicial do desenvolvimento embrionário do Rhamdia quelen e verificar suas respectivas taxas de fertilização, eclosão e sobrevivência. Os piretróides são inseticidas amplamente utilizados atualmente e apresentam alta toxicidade para peixes. Para determinação da concentração letal e subletal foram utilizados 120 jundiás com peso médio de $59,58 \pm 4,50 \mathrm{~g}$ e comprimento médio de $20,33 \pm 2,34 \mathrm{~cm}$. As concentrações utilizadas foram $0 ; 1,0 ; 1,5 ; 2,0 ; 2,5 ; 3,0 ; 5,0 ; 10,0 ; 15,0 \mathrm{e}$ $20,0 \mathrm{mg}$ de cipermetrina por litro de água $(\mathrm{mg} / \mathrm{L})$. Os peixes foram expostos ao produto dentro de aquários com capacidade para 30 litros. Em cada aquário foram colocados quatro peixes e cada tratamento teve três repetições, totalizando doze peixes por tratamento. Para determinar a concentração subletal da cipermetrina e deltametrina na fase de desenvolvimento embrionário foi realizada a indução da ovulação em fêmeas de jundiá através de hormônios, com posterior coleta dos ovos. Os ovos foram hidratados e fertilizados em soluções de cipermetrina e deltametrina em diferentes concentrações, sendo estas: 0,$001 ; 0,01$; 0,$1 ; 1,0$ e $10,0 \mathrm{mg} / \mathrm{L}$ para cipermetrina e 0,$001 ; 0,01 ; 0,1$; 0,5 e $1,0 \mathrm{mg} / \mathrm{L}$ para deltametrina, além do grupo controle $(0 \mathrm{mg} / \mathrm{L})$. Após a fertilização, os ovos permaneceram em recipientes com os respectivos pesticidas até o momento da eclosão onde foi analisada a taxa de eclosão. Em seguida as larvas, a partir da eclosão dos ovos, foram mantidas nas respectivas concentrações de cipermetrina e deltametrina para analisar a taxa de sobrevivência frente aos inseticidas testados, durante 12 e 24 horas. Em relação as concentrações letais e subletais de jundiás jovens, estes apresentaram-se sensíveis à cipermetrina nas concentrações testadas, apresentando sinais de intoxicação como perda de equilíbrio, alteração na natação, dispnéia mantendo a boca e os opérculos abertos, nados verticais e movimentos súbitos de natação em forma de espiral. A intensidade destes sinais variou proporcionalmente a concentração utilizada. As concentrações acima de $3,0 \mathrm{mg} / \mathrm{L}$ foram consideradas letais para a espécie em 96 horas, pois todos os animais expostos a concentrações entre 3,0 e $20,0 \mathrm{mg} / \mathrm{L}$ vieram a óbito, enquanto que as concentrações entre 1,0 e $2,5 \mathrm{mg} / \mathrm{L}$ são subletais. $\mathrm{A} \mathrm{CL}_{50} 96$ horas da cipermetrina para o jundiá foi $1,71 \mathrm{mg} / \mathrm{L}$. Em relação aos efeitos da cipermetrina e deltametrina sobre a fase de desenvolvimento embrionário, os resultados mostraram que ambos os piretróides diminuíram significativamente os parâmetros analisados em comparação com o grupo controle. Conclui-se que mes- mo o jundiá mostrando ser mais resistente aos piretróides em comparação com outras espécies, tanto animais jovens como animais em fase de desenvolvimento embrionário mostraram-se sensíveis aos efeitos destes pesticidas.

TERMOS DE INDEXAÇÃO: Piretróides, pesticidas, Jundiá, Rhamdia quelen, desenvolvimento embrionário, peixes.

\section{INTRODUCTION}

New pesticides were recently developed intended to general use on environment. Such insecticides tend to be toxic to fish and other aquatic organisms. Several products containing Pyrethroids are classified as 'limited use pesticides', by the Environmental Protection Agency, due to their toxicity to fish (Aydin et al. 2005, Saha \& Kaviraj 2009).

The impact of contamination by agro toxins both in fish and macroinvertebrates varies according to the kind of substances used, their toxicity levels and the stability on aquatic environments (Arias et al. 2007). The sublethal concentrations might be influenced by other factors, including strain of the animal, age and gender, as well as other environmental parameters, such as temperature, water hardness and pH (Bernardi et al. 2008). The effects of agro toxins in fish may vary from mass lethality of scales up to several sublethal effects, affecting the entire community structure (Arias et al. 2007).

Pyrethroids are synthetic insecticides which present a wide activity range, fast action, and efficiency on low dosage, low residual power, and low toxicity to mammals, when compared to other insecticides (WHO 1990, Barrionuevo \& Lanças 2001).

Pyrethroids are largely used as terrestrial and aquatic pesticide; they act on the functioning of the central nervous system, through ion channels on nerve cells, causing hyperactivity and subsequent lack of control of the normal functions (Borges 2005).

In general, Pyrethroids are virtually non-toxic to mammals and birds, but is highly toxic to fish and aquatic invertebrates. The main reason is that metabolism and elimination of such compounds are significantly slower in fish than in mammals and birds (Yilmaz et al. 2004, Begum 2005).

Several studies in laboratories have been conducted, which prove that Cypermethrin is highly toxic to fish, even in very low concentrations, varying from 0.4 to $2.2 \mu \mathrm{g} / \mathrm{L}$ in 96 hours for some species (David et al. 2004).

Aquatic toxicity tests provide information on the potential danger of the effects of a toxic substance on aquatic organisms (Rodrigues 2007). The effects regarding survival or mortality of the organisms, as well as behavioral, morphological and physiological effects are evaluated (Massaro 2006). 
The effects of pollutants on natural ecosystems may be measured by their effects on reproductive processes (Tripathi \& Singh 2004). The reproductive parameters are the most complex indicators of exposure and accumulation of chemical agents, difficult by several reasons; the main ones are the direct and indirect effect of pollutants on reproduction and the physiological process (Bernardi et al. 2008).

Close attention has been recently given to possible adverse effects resulting from exposure of aquatic animals to chemical agents during the prenatal stage and perinatal period (Tramujas et al. 2006). Several xenobiotics are known to affect reproduction of many organisms. For this reason, it is important to evaluate the responses of such compounds in relation to the reproductive parameters (Mayon et al. 2006).

Moore \& Waring (2001) have reported decrease on the fertility rate in Atlantic salmon (Salmo salar) after being exposed to pyrethroids. Tramujas (2005) has reported decrease on the hatching rate of zebrafish (Danio rerio) exposed to Deltamethrin. But Tramujas et al. (2006) when exposing zebrafish (Danio rerio) to Deltamethrin has not observed change on the hatching rate. Aydin et al. (2005) reported decrease on common carp (Cyprinus carpio) exposed to Cypermethrin.

A wide toxicological study of several substances is necessary, since more than a thousand new synthetic chemical substances are released every year, most of them with no proper evaluation regarding their interaction on the ecosystems (Bernardi et al. 2008). This way, this paper aims to determine the lethal and sublethal concentration of Cypermethrine to young Silver Catfish (Rhamdia quelen), during a 96-hour period; to determine the sublethal concentration of Cypermethrin and Deltamethrin during the initial embryonic development of Rhamdia quelen and to verify their respective fertilization, hatching and survival rates.

\section{MATERIALS AND METHODS}

The species chosen were Rhamdia quelen, a river fish native from the south of Brazil, popularly known as "jundiá" (Silver Catfish). The experimental testing was conducted at the Fish Farming and Research Laboratory (LAPEP), in the Fish Farming Area from Patronato Santo Antônio da Pontifícia Universidade Católica do Paraná (PUCPR). The testing was approved by the Ethics Committee on Animal Use (CEUA/PUCPR, protocol number 439).

The commercial products tested, Cypermade 250 SC (Which has Cypermethrin as active substance) and Fulmiprag 25 SC (Which has Deltamethrin as active substance) were donated by the Company ADD Atlanta, which was also responsible for the generated effluents.

\section{Methodology for evaluation of behavioral changes and mor- tality}

The fish were taken out of the tanks and acclimatized for fifteen days in 1000-liter stock-aquariums, properly disinfected. The water temperature has been kept around $24 / 25^{\circ} \mathrm{C}$, with constant aeration, pH level around 7.0 and biological filtration. The fish were fed with commercial fish food once a day, and one third of the water from the acclimatizing tank was changed every three days.
Before starting the testing itself, some 30-liter tanks were prepared; in the same conditions of acclimatization. The tanks were wrapped in dark plastic bags during the 96-hour period in order to avoid both the photodegradation of the pyrethroid and the stress on animals due to luminosity.

The fish were measured and weighed individually. The medium weight was $58.59 \pm 4.50 \mathrm{~g}$ and the medium length was $20.33 \pm 2.34 \mathrm{~cm}$.

The Cypermethrin concentrations used in the testing water were $0,1,1.5,2,2.5,3,5,10,15$ and $20 \mathrm{mg} / \mathrm{L}$, which were randomly applied in the water according to a draw, in a static system. Four fish were placed in each tank and each application has been repeated three times, in total a number of 120 animals $(n=120)$. The testing was conducted in 96 hours. During this period of time, the animals had not been fed.

During the test, dead animals were taken out of the tanks. Mortality rates were measured at 24, 48, 72 and 96 hours after the first exposure to the product.

In order to determine the sublethal concentration $\left(\mathrm{CL}_{50}\right)$, calculations were performed by using Tablecurve 2D software, version 5.01. In order to statically analyze the data, the Kruskal-Wallis test was used; afterwards, Dunn's test and the Graphpad Prism statistical software (version 3.00 for Windows, San Diego, California, USA) were both used in order to make comparisons between the groups. The significance level used was $5 \%$ $(\mathrm{p}<0.05)$.

\section{Methodology for evaluation of reproductive parameters}

The fish had reproduction induced by application of macerated pituitary gland of common carp, according to Woynarovich \& Horvath (1983) techniques. After the 24-hour induction period, the oocyte from females was removed $(n=7)$ and the semen from the males have been collected $(n=3)$. The oocytes from all females and the semen were put together. Fifty $\mathrm{ml}$ of eggs were collected from the mixture; they were hydrated and fertilized with different concentrations of Cypermethrin and Deltamethrin in different containers.

After being hydrated with different concentrations of Cypermethrin $(0 ; 0.001 ; 0.01 ; 0.1 ; 1.0$ and $10.0 \mathrm{mg} / \mathrm{L})$ and Deltamethrin $(0,0.001,0.01,0.1,0.5$ and $1.0 \mathrm{mg} / \mathrm{L})$, the fertilized eggs were placed in hatcheries with controlled temperatures $\left(26-27^{\circ} \mathrm{C}\right)$ and constant aeration. Six hours after fecundation, the fertility rate was determined by taking $10 \mathrm{~mL}$ of eggs from each hatchery. They were then placed on Petri dishes so that the fertilized and rotten eggs could be counted. In order to determine this rate, such process was repeated six times.

The next step was to separate 50 viable eggs from the fertilized ones, which were placed in identified 500-mL containers; such containers had the same concentrations of Cypermethrin $(0$; $0.001 ; 0.01 ; 0.1 ; 1.0$ and $10.0 \mathrm{mg} / \mathrm{L})$ and Deltamethrin $(0,0.001$, $0.01,0.1,0.5$ and $1.0 \mathrm{mg} / \mathrm{L}$ ). This step was repeated six times, one time for each concentration.

Twenty-one hours after the incubation, the hatching of eggs started, i.e., twenty-seven hours after fertilization, according to the methodology described by Silva (2004). On this phase, the counting of the hatching eggs was done; the rotten eggs were counted and discarded. The hatching rate was then calculated.

After this step, the hatched alevins were kept on their respective insecticide concentrations for 12 hours in order to estimate the survival rate. Afterwards, the alive and dead alevins from the different concentrations were separated and exposed again to their respective insecticide concentrations for twelve hours in order to evaluate the survival rate for a 24 -hour exposure to insecticides. 
In order to perform the statistical analysis the Kruskal-Wallis test was used; afterwards, Dunn's test was used to perform a comparison between the averages. The significance level adopted was $5 \%(\mathrm{p}<0.05)$. The calculation was performed by using Graphpad Prism statistical software (version 3.0 for Windows, San Diego, California, USA). To determine the sublethal concentration $\left(\mathrm{CL}_{50}\right)$, the calculations were performed by using Tablecurve 2D software, version 5.01 .

\section{RESULTS}

\section{Results of behavioral changes and mortality}

The animals from the control group remained healthy during all the testing; no deaths occurred among the subjects of this group.

Fish exposed to Cypermethrin had symptoms such as loss of balance, swimming pattern changes, dyspnea (they kept both mouth and opercula open), upright swimming and sudden swimming spiral movements. The aforementioned symptoms had increased proportionally to the increasing of Cypermethrin concentrations. Fish exposed to $2.5,3,5,10,15$ and $20 \mathrm{mg} / \mathrm{L}$ concentrations tried to jump out from the aquariums at the moment of application. The symptoms started on the first 30 minutes after exposition to the product and lasted on some animals until the deadline ( 96 hours). Some animals succumbed and died.

Before dying, some fish become less active, remaining vertically in the water and, sometimes, motionless on the bottom of the tank.

Postmortem alterations observed on animals exposed to 10,15 and $20 \mathrm{mg} / \mathrm{L}$ concentrations of Cypermethrin included partial (and, in some cases, total) loss of pigmentation of the body surface, hyperemic and ulcerated lesions, with hemorrhagic signs in several parts of the body, as well as barbell erosions and tails with a degenerative appearance.

According to results obtained, it is possible to observe that concentrations above $3.0 \mathrm{mg} / \mathrm{L}$ of Cypermethrin may be considered lethal to Silver Catfish (Brazilian "Jundiá", Rhamdia quelen), since every fish died until 48 hours after the first exposure. Concentrations between 1 and $2.5 \mathrm{mg} / \mathrm{L}$ may be considered sublethal, since the fish had a mortality rate around $50 \%$ during the 96 hours of testing. The lethal concentration of Cypermethrin, in 96 hours, to Silver catfish was 1.71 milligram per liter of water.

\section{Results of reproductive parameters}

Deltamethrin. There was a decrease on the fertility rate of eggs as the eggs were exposed to higher concentrations of Deltamethrin, but there was a significant change $(p<0.05$ and $p<0.01)$ on groups with concentrations of 0.01 and $0.1 \mathrm{mg} / \mathrm{L}$ of Deltamethrin, showing an average of $26.98 \pm 7.04$ and $26.33 \pm 6.71$, respectively, of fertilized eggs in relation to the group with concentrations of 0 and 0.001 of Deltamethrin, which showed an average of $73.92 \pm 6.88$ and $74.98 \pm 15.65$ respectively.

There was a decrease on the hatching rate as they were exposed to higher Deltamethrin concentrations. There was a significant difference $(\mathrm{p}<0.01)$ on the group with concentrations of $0.1,0.5$ and $1 \mathrm{mg} / \mathrm{L}$ of Deltamethrin, showing an average of $4.50 \pm 2.16,15.67 \pm 15.36$ and $0.33 \pm 0.81$ res- pectively, in relation to the group with a concentration of $0 \mathrm{mg} / \mathrm{L}(83.33 \pm 5.46)$. There was also a significant difference $(p<0.05)$ between the groups with concentrations of 0.1 and $1 \mathrm{mg} / \mathrm{L}$ of Deltamethrin in relation to the group with a concentration of $0.001 \mathrm{mg} / \mathrm{L}$ of Deltamethrin, which showed an average of $66.67 \pm 5.46$.

There was a trend of decreasing the survival rate of alevins as they were exposed to higher concentrations of Deltamethrin during the twelve-hour period following the hatching. There was a significant difference $(p<0.01)$ of the group with concentrations of $0.1,0.5$ and $1 \mathrm{mg} / \mathrm{L}$ of Deltamethrin in relation to groups with concentration of $0 \mathrm{mg} / \mathrm{L}$, which showed an average of $17.17 \pm 18.51 ; 17.00 \pm 20.58$; $8.33 \pm 20.41$ and $97.80 \pm 2.03$ respectively.

There was a trend of decreasing the alevins survival rate as they were exposed to higher Deltamethrin concentrations, during the 24-hour period after hatching. There was a significant difference $(\mathrm{p}<0.01)$ on the group with a concentration of $0.1,0.5$ and $1 \mathrm{mg} / \mathrm{L}$ of Deltamethrin, showing an average of $12.83 \pm 16.35 ; 14.67 \pm 17.36$ and $8.33 \pm 20.41$, respectively, in relation to the group with a concentration of $0 \mathrm{mg} / \mathrm{L}$ of Deltamethrin $(99.93 \pm 2.61)$.

Cypermethrin. There was a decrease on fertility rate of the eggs as they were exposed to lower concentrations of Cypermethrin. There was a significant difference $(\mathrm{p}<0.01)$ on the groups with concentrations of 0.001 and $0.1 \mathrm{mg} / \mathrm{L}$, with an average of $4.03 \pm 3.92$ and $3.70 \pm 2.28$, respectively, in relation to the group with a concentration of $0 \mathrm{mg} / \mathrm{L}$ $(73.92 \pm 6.88)$. There was also a significant difference $(\mathrm{p}<0.05)$ on the group with a concentration of $0.01 \mathrm{mg} / \mathrm{L}$, which presented an average of $7.83 \pm 0.86$ in relation to the group with a $0 \mathrm{mg} / \mathrm{L}$ concentration.

It was possible to observe a trend of decreasing the egg hatching rate as the eggs were exposed to lower concentrations of Cypermethrin. There was a significant difference $(p<0.05)$ on the groups with concentrations of $0.001,0.01$ and $0.1 \mathrm{mg} / \mathrm{L}$, with an average of $29.33 \pm 3.72,40.33 \pm 6.62$ and $40.00 \pm 2.53$ in relation to the group with a concentration of $0 \mathrm{mg} / \mathrm{L}(83.33 \pm 5.46)$.

There was a trend of decreasing the survival rate of $R h a$ mdia quelen alevins exposed to the highest Cypermethrin concentration for twelve hours after hatching. There was a significant difference $(p<0.01)$ on the group with a concentration of $10 \mathrm{mg} / \mathrm{L}$ of Cypermethrin, with an average of $78.95 \pm 11.02$ compared to the group with a concentration of $0 \mathrm{mg} / \mathrm{L}$ of Cypermethrin with an average of $97.80 \pm 2.03$.

There was a trend to decrease the survival rate of Rhamdia quelen alevins exposed to concentrations of 0.001 and $10 \mathrm{mg} / \mathrm{L}$ of Cypermethrin for 24 hours after hatching. There was a significant difference $(\mathrm{p}<0.01)$ on such groups, which presented an average of $79.41 \pm 7.68$ and $75.52 \pm 14.14$ respectively, compared to the group with a concentration of $0 \mathrm{mg} / \mathrm{L}$ of Cypermethrin, which presented an average of $96.93 \pm 2.61$.

\section{DISCUSSION}

\section{Behavioral changes and mortality}

The most important behavioral changes observed in this paper were related to breathing and neurological disorders; such alterations have corroborated conclusions of 
authors Polat et al. (2002), Yilmaz et al. (2004), regarding their testing of Cypermethrin in Guppies (Poecilia reticulata); Borges (2005) and Borges (2007) regarding their testing of Cypermethrin in Silver Catfish (Brazilian "Jundiá", Rhamdia quelen) and Kumar et al. (2007) who exposed Channa punctatus to Cypermethrin on their studies. The aforementioned authors have also related such alterations.

The alterations mentioned before might happen due to toxic effects caused by Cypermethrin on vertebrates. This pyrethroid causes a significant effect on sodium channels of nerve filaments, blocking their opening and closing, i.e., shortening their depolarization phase, increasing the entrance time of $\mathrm{Na}^{+}$ions into the inner part of the cell and delaying its finishing (Borges 2005, 2007, Bradberry et al. 2005, Santos et al. 2007, Velisek et al. 2006, 2007). In addition, they interact with GABA receptors (inhibitory neurotransmitter of the central nervous system) on nerve filaments (Borges 2005, 2007, Bradberry et al. 2005, Velisek et al. 2006, 2007).

Galeb (2010), when poisoning Silver Catfish (Rhamdia quelen), with Deltamethrin, observed that the color of body surfaces of the animals changed, from the normal color to a whitish one, showing hemorrhagic dots and ulcerated lesions throughout their bodies. This result was also observed on this study, being more perceptible on post mortem alterations, which demonstrates the irritant effect of Cypermethrin on aquatic organisms.

This paper revealed that Cypermethrin dissolved in water is an insecticide toxic to Rhamdia quelen; the $3,5,10$, 15 and $20 \mathrm{mg} / \mathrm{L}$ concentrations might be considered lethal and the $1,1.5,2$ and $2.5 \mathrm{mg} / \mathrm{L}$ concentrations may be considered sublethal. Cypermethrin lethal concentration to Silver catfish was 1.71 milligram per liter of water, in 96 hours.

Several laboratory studies were conducted, and they proved that Cypermethrin is highly toxic to fish in very low concentrations, varying between 0.4 and $2.2 \mu \mathrm{g} / \mathrm{L}$ in 96 hours (David et al. 2004). According to Bradbury \& Coats (1989), the concentration of Cypermethrin which killed half the population of common carp (Cyprinus carpio) was between 0.9 and $1.1 \mu \mathrm{g} / \mathrm{L}$; to brown trout (Salmo trutta) was $1.2 \mu \mathrm{g} / \mathrm{L}$, to Nile tilapia (Tilapia nilotica) was $2.2 \mu \mathrm{g} / \mathrm{L}$, $0.5 \mu \mathrm{g} / \mathrm{L}$ to rainbow trout (Salmo gairdneri) and $0.4 \mu \mathrm{g} / \mathrm{L}$ to rudd (Scardinius erythropthalamus).

According to Borges $(2005,2007)$, Cypermethrin sublethal concentration to Silver Catfish (Rhamdia quelen) after 24, 48, 72 and 96 hours was $0.295,0.265,0.198$ and 0.193 ppm respectively.

Regarding Asian Stinging Catfish (Heteropneustes fossilis), the $0.96 \mu \mathrm{g} / \mathrm{L}$ concentration can cause $50 \%$ of mortality within 24 hours (Saha \& Kaviraj 2009). Cypermethrin sublethal concentration to Barbus choloensis, in 24 hours, is $20 \mu \mathrm{g} / \mathrm{L}$ (Yilmaz et al. 2004).

According to Das \& Mukherjee (2003), the Cypermethrin caused $10 \%$ of Labeo rohita carp to die in a concentration of $0.10 \mathrm{ppm}$ in 48 hours and caused $100 \%$ of mortality in a concentration of $0.20 \mathrm{ppm}$ in 72 hours. Analyses showed that the sublethal concentration in 24, 48, 72 and 96 hours was $0.225,0.162,0.149$ and $0.139 \mathrm{ppm}$ respectively.
The Cypermethrin sublethal concentration to guppy (Lebistes retuculatus) was determined as $21.35 \mu \mathrm{g} / \mathrm{L}$ (Çaliskan et al. 2003). The Cypermethrin sublethal concentration to ocean sunfish (Mola mola) was $1.8 \mu \mathrm{g} / \mathrm{L}$ (Polat et al. 2002).

Smith \& Stratton (1986) calculated the Cypermethrin sublethal concentration in $\mu \mathrm{g} / \mathrm{L}$ to the following species of fish: Atlantic salmon (Salmo solar): 2.0, in 96 hours; Mosquito fish (Gambusia affinis) 9.0, in 24 hours and 8.0, in 48 hours; Desert pupfish (Cyprinodon macularius): 10.0, in 24 hours and 6.0, in 48 hours.

The Cypermethrin sublethal concentration was $9.43 \mu \mathrm{g} /$ $\mathrm{L}$ (from 8.24 to 11.20 ) to guppy (Poecilia reticulate) (Yilmaz et al. 2004).

During a 96-hour period of exposure to Cypermethrin 0.1 and $0.2 \mathrm{mg} / \mathrm{L}$ concentrations, no Channa punctatus subjects died. Nevertheless, when the subjects were exposed to $0.3 ; 0.4 ; 0.5$ and $0.6 \mathrm{mg} / \mathrm{L}$ concentrations, the mortality percentage was $25,50,75$ and $100 \%$, respectively. So, the Cypermethrin sublethal concentration to this fish was 0.4 $\mathrm{mg} / \mathrm{L}$ and the lethal concentration was $0.6 \mathrm{mg} / \mathrm{L}$ (Smith \& Stratton 1986).

Galeb (2010), when testing Deltamethrin in Silver Catfish (Rhamdia quelen), reported the sublethal concentration between 1 and 1.5 and the lethal concentration above $1.7 \mathrm{mg} / \mathrm{L}$.

Borges (2005), when testing Cypermethrin in Silver Catfish, reported sublethal concentrations lower than the ones reported in this study. This difference may be related to the gender and size of animals, since Borges used male animals, with weights and sizes larger than the ones used in this study. This difference may be also related to the formula toxicity of the active substance tested and to acclimatizing period, that was lower in this study; this factor is considered as stressing to the animals.

The difference between tested concentrations in several species may be related to the strain of the animal, age and gender, as well as other environmental parameters, such as temperature, water hardness and $\mathrm{pH}$, or even related to the toxicity of the tested chemical compounds, which are all factors that may intervene on the lethal and sublethal concentration values (Bernardi et al. 2008). This may be a contribution of this study, Silver Catfish proved to be more resistant to pyrethroids than other species, since all concentrations tested by the mentioned authors are lower than the concentrations used in this study.

\section{Reproductive parameters}

There are little data regarding the potential of sublethal effects of pesticides on the long-term effects on reproduction and viability on fish populations (Moore \& Waring 2001).

Recently, a great deal of attention was given to the possible adverse effects resulting from exposing aquatic animals to chemical agents. Moore \& Waring (2001) studied the exposure of salmon (salmo salar) eggs to Cypermethrin and observed a decrease of fertilization rate when compared to the control group, what is compatible with the result obtained on this study. 
Tramujas (2005) when testing Deltamethrin on zebrafish (Danio rerio) observed a decrease on egg hatching rate after exposure, according to results obtained on this study. Tramujas et al. (2006) did not report significant change on zebrafish (Danio rerio) hatching rate after exposure to sublethal concentrations of Deltamethrin.

Aydin et al. (2005) reported mortality of common carp (Cyprinus carp) alevins after 12 hours of exposure to Cypermethrin.

The results obtained on this study corroborate the results of Saravana \& Geraldine (2000), which reported that high concentrations of Deltamethrin showed a survival deficit to aquatic organisms.

Tramujas et al. (2006) reported changes on histological levels on gonads of aquatic organisms subjected to different concentrations of Deltamethrin, which can be analyzed on future studies. Besides, exposure to pyrethroids can intervene on the reproductive system, since such chemical agents are able to intervene on the endocrine system.

\section{CONCLUSIONS}

Cypermethrin concentrations above $3 \mathrm{mg} / \mathrm{L}$ can be considered lethal to young Silver Catfish (Rhamdia quelen), since all tested animals died after been exposed to it. Concentrations between 1 and $1.25 \mathrm{mg} / \mathrm{L}$ may be considered sublethal due to the partial mortality rate shown in this study.

Lethal concentration of Cypermethrin, in 96 hours, to young Silver catfish was 1.71 milligram per liter of water. Compared to other species, Silver catfish (Rhamdia quelen) proved to be relatively more resistant to Cypermethrin exposure.

According to results, Deltamethrin and Cypermethrin were considered toxic to Silver catfish on embryonic development and while the fish are still alevins.

Concentrations of 0.01 and $0.1 \mathrm{mg} / \mathrm{L}$ of Deltamethrin showed to be toxic to fertilization of Silver catfish eggs. On the other hand, concentrations of $0.1,0.5$ and $1.0 \mathrm{mg} / \mathrm{L}$ of Deltamethrin showed to be toxic to Silver catfish eggs and alevins hatching/survival rates in 12 and 24 hours.

Concentrations of $0.001,0.01$ and $0.1 \mathrm{mg} / \mathrm{L}$ of Cypermethrin proved to be toxic to Silver Catfish during embryonic development, in relation to fertilization and hatching rates. Regarding the 12 and 24-hour survival rate, the $10 \mathrm{mg} / \mathrm{L}$ concentration was proved to be toxic to Silver catfish eggs and alevins. The concentration of $0.001 \mathrm{mg} / \mathrm{L}$ of Cypermethrin also proved to be toxic with regard to 24 -hour survival rate.

\section{REFERENCES}

Arias A.R.L., Buss D.F., Alburquerque C., Inácio A.F., Freire M.M., Egler M., Mugnai R. \& Baptista D.F. 2007. Utilização de bioindicadores na avaliação de impacto e no monitoramento da contaminação de rios e córregos por agrotóxicos. Ciência e Saúde Coletiva 12(1):61-72.

Aydin R., Koprucu K., Dorucu M., Koprucu S.S. \& Pala M. 2005. Acute toxicity of synthetic pyrethroid cypermethrin on the common carp (Cyprinus carpio L.) embryos and larvae. Aquacult. Int. 13:451-458.

Barrionuevo R.W. \& Lanças F.M. 2001. Extração em fase sólida (SPE) e micro extração em fase sólida (SPME) de piretróides em água. Química Nova 24:172-175.

Begum G. 2005. In vivo biochemical changes in liver and gill of Clarias ba- trachus during cypermethrin exposure and following cessation of exposure. Pesticide Biochemical and Physiology 82:185-196.

Bernardi M.M., Moraes R.C., Varoli F.M.F. \& Osti S.C. 2008. Ecotoxicologia, p.815-858. In: Spinosa H.S., Gómiak S.L. \& Palermo-Neto J. (Eds), Toxicologia Aplicada à Medicina Veterinária. Manole, São Paulo. 942p.

Borges A. 2007. Changes in hematological and serum biochemical values in Jundiá Rhamdia quelen due to sub-lethal toxicity of cipermethrin. Chemosphere 69:920-926.

Borges A. 2005. Valores hematológicos e bioquímicos séricos, efeitos de doses sub-letais da cipermetrina e características físico-químicas do sêmem do Jundiá Rhamdia quelen. Tese de Doutorado em Ciências Biológicas, Universidade Federal do Rio Grande do Sul, Porto Alegre. 175p.

Bradberry S.M., Cage S.A., Proudfoot A.T. \& Vale J.A. 2005. Poisoning due to pyrethroids. Toxicol. Rev. 24(2):93-106.

Bradbury S.P. \& Coats J.R. 1989. Comparative toxicology of phyrethroid insecticides. Rev. Environ. Contamin. Toxicol. 108:133-177. (Apud Yilmaz et al. 2004)

Çaliskan M., Erkmen B. \& Yerli S.V. 2003. The effects of zeta cypermethrin on the gills of common guppy Lebistes reticulates. Environ. Toxicol. Pharmacol. 14:117-120.

Das B.K. \& Mukherjee S.C. 2003. Toxicity of cypermethrin in Labeo rohita fingerlings: biochemical, enzymatic and haematological consequences. Comp. Biochem. Physiol. 134:109-121.

David M., Mushigeri S.B., Shivakumar R. \& Philip G.H. 2004. Response of Cyprinus carpio (Linn) to sublethal concentration of cypermethrin: alterations in protein metabolic profiles. Chemosphere 56:347-352.

Galeb L.A.G. 2010. Avaliação dos efeitos toxicológicos da deltametrina em uma espécie de peixe fluvial nativo jundiá (Rhamdia quelen). Dissertação de Mestrado em Ciência Animal, Pontifícia Universidade Católica do Paraná, Curitiba.

Kumar A., Sharma B. \& Pandey R.S. 2007. Preliminary evaluation of the acute toxicity of cypermethrin and $\alpha$-cyhalothrin to Channa punctatus. Bull. Environ. Contamin. Toxicol. 79:613-616.

Massaro F.C. 2006. Estudos ecotoxicológicos com Hydra viridissima (Cnidaria: Hydrozoa). Dissertação de Mestrado em Ciências da Engenharia Ambiental, Escola de Engenharia de São Carlos, Universidade de São Paulo, São Carlos. 108p.

Mayon M., Bertrand A., Leroy D., Malbrouck C., Mandiki S.N.M., Silvestre F., Goffart A., Thomé J.-P. \& Kestemont P. 2006. Multiscale approach of fish responses to different types of environmental contaminations: A case study. Science of the Total Environmental 367:715-731.

Moore A. \& Waring C.P. 2001. The effects of a synthetic pyrethroid pesticide on some aspects of reproduction in Atlantic Salmon (Salmo salar L.). Aquatic Toxicol. 52:1-12.

Polat H., Erkoç F.U., Viran R. \& Koçak 0. 2002. Investigation of acute toxicity of beta-cypermethrin on guppies Poecilia reticulata. Chemosphere 49:39-44.

Rodrigues B.K. 2007. Avaliação dos impactos de agrotóxicos na região do Alto Mogi-Guaçu (MG) por meio de ensaios laboratoriais com Danio rerio (Cypriniformes, Cyprinidae). Dissertação de Mestrado, Escola de Engenharia de São Carlos, Universidade de São Paulo, São Carlos. 138p.

Saha S. \& Kaviraj A. 2009. Effects os cypermethrin on some biochemical parameters and its amelioration through dietary supplementation os ascorbic acid in freshwater catfish Heteropneustes fossilis. Chemosphere 74:1254-1259.

Santos M.A.T., Areas M.A. \& Reyes F.G.R. 2007. Piretróides: uma visão geral. Alimentos e Nutrição, Araraquara 18(3):339-349.

Saravana B.P. \& Geraldine P. 2000. Histopathology of the hepatopancreasand gills of the prawn Macrobrachium malcomsonii exposed to endosulfan. Aquatic Toxicol. 50:331-339.

Silva L.V.F. 2004. Reprodução, p.95-106. In: Baldisserotto B. \& Radünz Neto J. (Eds), Criação de Jundiá. UFSM, Santa Maria.

Smith T.M. \& Stratton G.W. 1986. Effects of synthetic pyrethroid insecticides on nontarget organisms. Res. Review 97:93-119. (Apud Polat et al. 2002, Kumar et al. 2007)

Tramujas F.F. 2005. Avaliação dos efeitos reprodutivos de doses subletais 
de deltametrina em peixe zebra (Danio rerio). Universidade Federal do Paraná, Curitiba.

Tramujas F.F., Fávaro L.F., Pauka L.M. \& Silva de Assis H.C. 2006. Aspectos reprodutivos do peixe-zebra, Danio rerio, exposto a doses subletais de deltametrina. Archs Vet. Sci. 11(1):48-53. (Printed in Brazil)

Tripathi P.K. \& Singh A. 2004. Toxic effects of cypermethrin and alphamethrin on reproduction and oxidative embolism of the freshwater snail, Lymnaea acuminate. Ecotoxicology and Environmental Safety 58:227-235.

Velisek J., Jurciková J., Dobsiková R., Svobodová Z., Piacková V., Máchová J. \& Novotny L. 2007. Effects of deltamethrin on rainbow trout (Oncorhynchus mykiss). Environmental Toxicol. Pharmacol. 23:297-301.
Velisek J., Wlasow T., Gomulka P., Svobodova Z., Dobsikova R., Novotny L. \& Dudzik M. 2006. Effects of cypermethrin on rainbow trout (Oncorhynchus mykiss). Veterinarni Medicina 51(10):469-476.

Yilmaz M., Gul A. \& Erbasli K. 2004. Acute toxicity of alpha-cypermethrin to guppy (Poecilia reticulate, Pallas, 1859). Chemosphere 56:381-385.

WHO 1990. Environmental health criteria 97 - deltamethrin. International Programme on Chemical Safety (IPCS), World Health Organization, Geneva.

Woynarovich E. \& Horváth L.A. 1983. Propagação artificial de peixes de águas tropicais. Manual de Extensão 5, FAO/CODEVASF-CNPq, Brasília, DF. 220p. 